\title{
Varieties of capitalism in central and eastern Europe: measuring the co-ordination index of a national economy 1
}

\begin{abstract}
Why do some countries struggle with unemployment, while others are experiencing solid economic growth? Based on the assumption that there are several ways to achieve economic prosperity, the 'varieties of capitalism' approach explains the differences and institutional advantages of nations. This article departs from the Hall and Soskice (2001) framework of the varieties of capitalism and focuses on central and eastern Europe. The aim of the study is to investigate the form of co-ordination of economic actors in the sample countries. In this study, we employ quantitative techniques to identify what kind of capitalism has emerged in central and eastern European countries. The research attempts to define the extent of co-ordination in individual countries and to express this difference in a numerical way. The result of the study is a coordination index, appropriate to be used in further research in the field of political economy.
\end{abstract}

Keywords: varieties of capitalism, co-ordination index, central and eastern Europe, new EU member states, liberal market economy, co-ordinated market economy

Introduction

Why are some countries growing faster than others? Why are some states successful at fighting unemployment while others face strikes? To what extent could economic growth be influenced by government policies? Questions like these have, for a long time, motivated research in the comparative political economy. Different modes of production or government policies in developed countries indicate that there is no such thing as a single, universal, capitalism. Countries have developed different legal norms and informal institutions which give incentives to the behaviour of different actors. Current research suggests that it is the co-ordination of these actors that might lead to the international comparative advantage of countries and, thus, to better economic performance.

This article focuses on measuring the level of co-ordination of actors in central and eastern European countries, on the assumption that different types of capitalism have evolved in post-communist countries. Departing from the 'varieties of capitalism' (VoC) concept (Hall and Soskice, 2001), we apply quantitative methods to identify the type of capitalism that exists in central and eastern Europe. In order to determine the

1 This work was supported by the Slovak Research and Development Agency under contract No. APVV-0660-06. 
position of countries in central and eastern Europe according to the VoC concept, we construct a composite co-ordination index, based on the character and strength of the co-ordination of the actors concerned.

After this introduction, there follows a brief review of the concept of varieties of capitalism, the cornerstone of this research study, and its applicability to post-communist countries. After that, we review the position of central and eastern European countries in the $\mathrm{VoC}$ literature. Before constructing the composite index, we explain the selection of variables and the sample countries. A clarification of the methodology is followed by the results of this research. The conclusion not only sums up the findings but also outlines the possible use of the index in future research.

\section{Varieties of capitalism}

The varieties of capitalism approach has been developed around institutional analysis, specifically the new institutionalism. The major substance of this way of thinking is a focus on the other than formal institutions that shape and channel human behaviour. The new institutionalism seeks to elucidate the role that institutions play in the determination of social and political outcomes. Explanations of the new institutionalism emphasise path-dependence and man-made constraints (Parsons, 2007: 68). Hall and Taylor point out that the new institutionalism is not 'a unified body of thought' (1996: 936); however, there are at least three recognisable lines of thinking. The major difference should be perceived in regard to the two fundamental questions they attempt to answer:

How to construe the relationship between institutions and behavior and how to explain the process whereby institutions originate or change. (Hall and Taylor: 937)

There is not a clear consensus on the exact number and categorisation of approaches within the new institutionalism, but this article focuses on one: that of rational choice institutionalism.

Rational choice institutionalism assumes that all relevant actors see politics and society as 'a series of collective action dilemmas' (Hall and Taylor, 1996: 945). Departing from the game-theory approach, this means that actors take actions with a secondary, sub-optimal outcome. Hall and Taylor explain:

Typically, what prevents them from taking a collectively-superior course of action is the absence of institutional arrangements that would guarantee complementary behavior by others.

The varieties of capitalism concept answers this problem with reference to the concept of institutional complementarities.

Several scholars have contributed to the development of rational choice institutionalism (chiefly North, 1990; Scharpf, 1997; Peters, 1999; and Ostrom, 2005) and a widely-accepted definition of institutions has been established. Institutions are seen as: 
The rules of the game in a society or, more formally, the humanly devised constraints that shape human interaction. In consequence they structure incentives in human exchange, whether political, social, or economic. (North, 1990: 3)

However, one should not confuse institutions with organisations. The latter:

Provide a structure to human interaction ... They are groups of individuals bound by some common purpose to achieve objectives. (North, 1990: 4-5)

To put it in other words, both human beings and organisations live in a type of institutional setting which shapes their behaviour and which provides incentives for certain sort of actions and restraints against others. Institutions represent the rules of the game in which individuals take part.

The idea that different modes of production can lead to the same result was developed decades ago and is not new in the field of political economy. Several scholars have conducted research into the different types of capitalism. After analysing 'western' national economies, Hall and Soskice (2001) came up with the varieties of capitalism approach.

Hall and Soskice assigned firms a central place in the varieties of capitalism approach. They:

Are the key agents of adjustment in the face of technological change or international competition whose activities aggregate into overall levels of economic performance. (Hall and Soskice, 2001: 6)

On the other hand, companies are dependent on other actors within the national economy in order to solve everyday problems of production. Thus, Hall and Soskice's conception of the firm is relational.

We take the view that critical to these is the quality of the relationships the firm is able to establish, both internally, with its own employees, and externally, with a range of other actors that include suppliers, clients, collaborators, stakeholders, trade unions, business associations, and governments.

To put it another way, firms are forced to co-ordinate their activities with suppliers and clients in order to ensure a flow of products. Co-operation with employees within the firm is necessary to ensure its core functioning. Communication with financial institutions is important when it comes to fundraising and new investments. Firms' cooperation with institutions providing education and training might be helpful to ensure firms have a labour force with a satisfactory level of skills. To sum up, the effective organisation of production is dependent on firms' relations and co-ordination with other agents in the national economy. Hall and Soskice view firms as actors and, therefore, base their concept on rational choice institutionalism. 
Based on the above, 'co-ordination' has become the keyword in the varieties of capitalism approach. Now, it is time to link it to two of the other basic concepts developed by Hall and Soskice: institutional complementarities; and comparative institutional advantages. According to the authors:

The institutional structure of a particular political economy provides firms with advantages for engaging in specific types of activities there. Firms can perform some types of activities, which allow them to produce some kinds of goods, more efficiently than others because of the institutional support they receive for those activities in the political economy, and the institutions relevant to these activities are not distributed evenly across nations. (Hall and Soskice, 2001: 37)

Institutional complementarities are, therefore, the result of actors' strategic interaction over time. Consequently, nations with a particular type of co-ordination in one sphere of the economy should tend to develop complementary practices in other spheres as well. Such an effect results in the comparative advantage of one country over others.

For the purpose of this research study, it is inevitable to list the five key spheres of co-ordination identified by Hall and Soskice, and adopted by many others. These are:

a) industrial relations - questions on how to co-ordinate bargaining over wages and working conditions with the labour force, the organisations that represent labour and other employers. At stake here are the wage and productivity levels that condition the success of the firm and the rates of unemployment and inflation in the economy as a whole

b) vocational training and education - the problem of securing a workforce with suitable skills, while workers face the problem of deciding how much to invest in what skills. On the outcomes of this co-ordination problem turn not only the fortunes of individual companies and workers, but the skill levels and competitiveness of the overall economy

c) corporate governance - the problem of access to finance by firms and the extent to which investors seek assurances from firms of a return on their investments. The solutions devised to these problems affect both the availability of finance for particular types of projects and the terms on which firms can secure funds

d) inter-firm relations - this covers the relationships that a company forms with other enterprises and, notably, its suppliers or clients. These refer to particular endeavours that may encompass standard-setting, technology transfer and collaborative research and development. Here, co-ordination problems stem from the sharing of proprietary information and the risk of exploitation in joint ventures. Dependent on the results are the capacities of firms to remain competitive and the level of technological progress in the economy as a whole

e) employee sphere - this answers how we ensure that employees have the requisite competencies and that they co-operate well with others to advance the objectives of the firm. The relationships that firms develop to resolve these problems condition their own competencies, as well as the character of an economy's production regimes. (Based on Hall and Soskice, 2001: 7) 
Ideal types: the liberal and the co-ordinated market economy

Based on how problems are solved in particular national economies, and how different actors in those economies co-ordinate their activities, Hall and Soskice identified two ideal-types of capitalist institutional setting: the liberal market economy; and the co-ordinated market economy. This distinction between what are predominantly firmbased relationships departs from the assumption that the different types 'var[y] systematically across nations' (Hall and Soskice, 2001: 9). Indeed, these two types represent different modes of co-ordination (competitive or strategic). Moreover, different institutional arrangements are necessary to provide complementary incentives and constraints on the economic behaviour of the actors.

The liberal market economy is the system represented by relations that are coordinated by market mechanisms. A free market, perfect competition, formal contracts and the arms-length price/principle are typical elements of such a system. Fundraising is based primarily on stock market investments and, therefore, reputation and the current profits of firms are important. This requires a de-regulated labour market and decentralised wage bargaining. In order to ensure this, government policies pursue lower levels of worker protection which, in turn, leads to the flexible hiring and firing of employees. Such an environment provides incentives for workers to invest their time and money into general and broadly-applicable skills so as to ensure that they can easily find their place on the labour market. The education system thus offers more general than specific training. Knell and Srholec add:

Strong anti-trust legislation also limits possible cooperation between firms and implies technology transfer based on labour mobility and licensing; market driven standard setting; etc. (Knell and Srholec, 2005: 6)

According to Hall and Soskice, the United States of America is an example which is very close to the ideal type of liberal market economy.

At the other end of the continuum stands Germany. In the varieties of capitalism literature, Germany represents the ideal type of co-ordinated market economy, where market and informal co-ordination tools dominate socio-economic relations. Firms resolve everyday problems via strategic interaction with their partners. In order to achieve long-term equilibrium in such an environment, supportive institutions are needed. Firms usually have access to capital which Hall and Soskice call 'patient', while problems are generally resolved through a dense network of companies and investors within industries. This links together managers, technical personnel and bankers who share private and reliable information about each other's business. The purpose of sharing this kind of information with third parties is, for the most part, to secure the monitoring behaviour of companies and to take sanctions against misleading statements. Large industrial associations and extensive networks of firms and their suppliers, clients and other companies allow the effective co-ordination of standard-setting, vocational training, joint research, product development, etc. Companies are not sensitive to current earnings, so they can focus on long-term investments, incremental innovation and research projects. 
All this is, however, dependent on a legal and institutional environment that discourages hostile takeovers and provides incentives for the creation and maintenance of networks and cross-shareholding.

According to the authors, both kinds of capitalism are able to ensure their people of high levels of well-being and effective production, leading to solid long-term growth. However, it is important that societal institutions are mutually complementary. The examples of USA and Germany illustrate how different public policies - the products of political decisions - might be complementary to each other and how, therefore, they might increase the efficiency of the national economy as a whole.

At the same time, it is clear that the liberal market economy has different institutional advantages which are supportive of different regimes of production compared to the co-ordinated market economy.

Applicability to central and eastern Europe, and alternative approaches

The original varieties of capitalism approach was developed with regard to the-then western states and OECD members. However, the region of central and eastern Europe, with the economic transition in its final stage, has attracted the attention of many scholars. The eight post-communist states which entered the European Union in 2004 proved that at least some of the countries had developed market economies and the corresponding institutions.

However, applying the $\mathrm{VoC}$ concept to post-communist countries raises some questions. The first of these relates to doubts about whether the economic system that has been developed is capitalist at all. Lane and Myant (2007: 19) present a brief and transparent table focusing on the basic components of modern capitalism (see Figure 1). Many of the criteria are similar to, if not the same as, the Copenhagen criteria set by the Treaty on European Union. Once a country has entered the EU, we could thus consider it to be a state with modern capitalist institutions. Nevertheless, there are reasonable doubts as to whether several CIS or Balkan countries are able to fulfil the institutional requirements related to property rights, political stability or a system of law enforcing private ownership.

Bluhm pointed out that the former CIS states have developed a:

Patrimonial and neo-patrimonial system ... in which state and economy remain interwoven in clientelist networks. (Bluhm, 2010: 202)

On top of that, the $\mathrm{VoC}$ approach also places importance on international competition and the division of labour. In this regard, Bluhm points out that the framework:

Takes into account primarily countries with privileged market positions. (Bluhm, 2010: 203)

Here again, we see a major difference between countries which are inside the EU and those that remain outside it.

One of the biggest issues related to the transfer of the VoC concept to post-communist Europe touches upon the problem of the institutional heritage of communist 
times. The economy was planned and close to collapse in the end, but there were many institutions in place before 1989 in states like Czechoslovakia and the Baltic states. These may have been ineffective prior to 1989 , but most of them remained in place subsequently. The transition to a market economy thus witnessed a mix of the two processes. On the one hand, new institutions (e.g. financial markets, business laws, etc.) had to be built from scratch; on the other, many existing institutions had to be transformed or integrated into the new political and economic system. The interaction between these two processes and their effect on capitalism is something that has not yet been clarified.

Figure 1 - Components of modern capitalism

\section{Economic:}

1. Private ownership of the means of production

2. Market-based monetary exchange of commodities for profit, leading to the renewed accumulation of capital

3. Competition between units of capital (firms, companies)

4. Wage labour

\section{Psychological:}

1. Entrepreneurs with the propensity to invest to accumulate capital

2. A work orientation on the part of the population

\section{Political:}

1. An appropriate type of government - one with limited powers over the economy and ownership but sufficient to maintain economic and political stability

2. A system of law capable of enforcing private ownership of property and a free market system

\section{Societal:}

1. Ideology - the values of accumulation and private property

2. Civil society giving rise to the autonomy of individuals with rights to combination and to the alienation of assets

3. A class structure derived from position in the economic order (1, 2 and 4 above).

Source: Lane and Myant, 2007.

Concerning alternatives to Hall and Soskice's classification, Lane and Myant (2007) have published one of the most comprehensive and informative qualitative studies of the varieties of capitalism in post-communist Europe. They also included several ex-Soviet republics in their analysis. Lane and Myant avoided the categorisation of Hall and Soskice while, in considering questions of equity, forms of ownership, the efficiency of the economy, industry and expert structure, and others, proceeded to identify three groups of states (2007: 35-36). 
Lane and Myant referred to the first group as being characterised by a 'state-led continental type' of market capitalism. It included the Višegrad group countries, as well as Estonia and Slovenia. According to Lane and Myant, these states approach the level of marketisation and privatisation of OECD countries; however, the welfare state is considerably more developed. This feature makes them 'distinct from Anglo-American countries'. The welfare state is, to a considerable degree, inherited from the socialist past while co-ordination is still dependent on the state. Lane and Myant identified a sub-group, consisting of Latvia, Lithuania, Romania, Bulgaria and Croatia - states that have 'lower levels of privatization and greater state coordination' (2007: 35) and which have developed appropriate governmental, societal and political institutions only because they have been 'tutored by the conditionality requirements of the EU and the IMF' (ibid.).

Hybrid state-market unco-ordinated capitalism is the second group labelled in Lane and Myant's classification. This consists of economically poorer countries (Russia, Ukraine, Georgia, Moldova, Kazakhstan...), having relatively high income inequalities and a low degree of integration in the global economy. Other important features are, according to Lane and Myant, low levels of domestic investment, a large FDI inflow to the energy sector and a:

Lack [of] the psychological, political and societal preconditions necessary to support modern capitalism.

The third group in Lane and Myant's classification includes those countries that have not yet developed a capitalist system (Uzbekistan, Belarus, Turkmenistan). On top of that, Lane and Myant believe that these are likely to remain statist economies. Typical features of such economic systems are low levels of private ownership and a high level of state control in the sphere of co-ordination and rule enforcement.

A valuable contribution to the analysis of central European capitalism has been made by Nölke and Vliegenthart (2009). Bluhm (2010) has pointed out that these authors combine elements of the VoC approach with dependency theory to introduce their own approach - a third type of capitalism typical of central and eastern Europe: the dependent market economy (Nölke and Vliegenthart, 2009). The authors question the applicability of the liberal and co-ordinated market economy models to central and eastern Europe because, in their reading of $\mathrm{VoC}$, this approach treats national economies as sovereign and independent and thus it excludes the 'external dependency' of the region (Nölke and Vliegenthart, 2009: 672). The dependent market economy has its own comparative advantages, namely in the assembly and production of complex consumer products, while institutional complementarities are based on skilled, but cheap, labour as well as the transfer of:

Technological innovations within transnational enterprises; and the provision of capital via foreign direct investment. (Nölke and Vliegenthart, 2009: 672) 
Co-ordination in the dependent market economy is 'alternative' and takes place from headquarters towards the local branches of transnational companies. The flow of innovation has the same direction.

What is innovative about this approach is that it incorporates transnational companies and their influence into the VoC framework. It also allows scholars to take into consideration the massive levels of foreign direct investment. This is how the authors explain the five spheres of co-ordination known from $\mathrm{VoC}$ : central and eastern European countries provide a pool of relatively skilled and cheap labour, and thus have become a place where technologically complex products may be assembled and sent out for further distribution.

Transnational companies allocate financial and technological means from their home country. It is only the results of research activities, not R\&D itself, which, in the end, finds its way to the central and eastern European region. Transnational companies favour a labour market which is flexible to a certain extent, so that they may adjust the amount of low-skilled workers relatively easily. At the same time, the labour market must not be too flexible, in order to prevent a high turnover of high-skilled employees. Transnational companies try to keep trade unions in a weak position and want to prevent strong unionisation or too-high wages: given production regimes based on round-theclock functioning, transnational companies can hardly afford extensive strikes and protests. Concerning the education and training sphere, the current level and quality of the education system is satisfactory for transnational companies and, thus, there is only limited private investment in R\&D.

However, despite questions being raised about the applicability of the VoC concept to central and eastern Europe, several scholars have already adopted such a view while paying little or no attention to the issue of transnationalism. Defining the relationship between such processes is far beyond the scope of this article, whose aim is to measure the level of co-ordination of economic actors in departing from the VoC concept. Before doing so, however, I briefly review in the next section the position of central and eastern Europe in the varieties of capitalism literature.

\section{Central eastern Europe capitalism}

One of the first scholars who applied the VoC approach to central and eastern Europe was Magnus Feldmann (2006). Feldmann compared Slovenia and Estonia, two very small and open economies facing severe international economic pressures. This makes:

Any observed variation in economic institutions particularly noteworthy. (Feldmann, 2006:

Feldmann showed that Slovenia has developed economic institutions corresponding to Hall and Soskice's co-ordinated market economy type, while Estonia could be placed at the other end of the continuum, i.e. close to a liberal market economy. Clemens Buchan has come to more or less the same result in his research (Buchan, 2005). 
Bohle and Greskovits (2007) broadened the sample of countries in question in their work, basing their analysis on countries' approaches to two opposing processes in the transition: the transformation of the economy from centrally-planned to market-oriented; and the level of social protection for citizens. Bohle and Greskovits argued that the eight new EU member states have developed a different pace and grade of institutionalisation concerning these processes. Based on this, they identified three types of capitalism in central and eastern Europe.

Neo-liberal capitalism has developed in the Baltic states, according to Bohle and Greskovits. The typical features of neo-liberal capitalism are very low growth rates of industrial production, a low level of output of complex products, a strict fiscal policy and the lowest levels of social protection.

At the other end of the scale, there is the neo-corporatist type of capitalism in Slovenia, represented by a high level of social protection, a relatively high share of complex exports and a country which is 'the least market-radical' (Bohle and Greskovits, 2007: 462).

The Višegrad countries, according to the authors, lie somewhere in between and are labelled by them as 'embedded neo-liberal'. Poland, Hungary, Czech Republic and Slovakia are more socially inclusive than the Baltic states. These states have:

Established measures and institutions of industrial policy and social welfare that make their neoliberalism embedded and distinctive,

but the Višegrad countries have still not established 'the institutions safeguarding macroeconomic stability' (ibid.).

Vanhuysse (2007) touched upon the varieties of capitalism issue in his study related predominantly to trade unions and to labour decline. The research deals mainly with the position of trade unions in central and eastern Europe, and related public policies, but Vanhuysse sought to fit the new EU member states into the varieties of capitalism framework, in the process coming to agreement with the classification of Bohle and Greskovits (Vanhuysse, 2007: 508).

Qualitative analysis has recently been evidently the more popular approach, but one will also find quantitative research into the varieties of capitalism concept in central and eastern Europe. Knell and Srholec were among the first to grasp the concept of coordination and to come up with a numeric expression for it. The authors based their analyses on three different types of institutional arrangement (Knell and Srholec, 2007: 6):

1. social cohesion

2. labour market regulations

3. business regulations.

Using statistical methods, they came to the co-ordination index set out in Table 1 (which concentrates on the 2004 EU entrants; for comparative purposes, the index for Germany and USA is also presented). 
Another composite indicator was constructed by Baláž (2006). Baláž took into consideration the business, labour market and financial market environments in OECD countries. The major shortcoming is that only the four Višegrad countries are included in the analysis, and thus it is impossible to compare it to the Baltic states or Slovenia. However, I present his composite index in Table 2 below (again together with Germany and the USA, as Hall and Soskice's 'ideal types').

Table 1 - Knell and Srholec's composite index of co-ordination

\begin{tabular}{|c|c|c|}
\hline & Country & $\begin{array}{l}\text { Co-ordination } \\
\text { Index }\end{array}$ \\
\hline & Slovenia & 6.3 \\
\hline \multirow{3}{*}{ 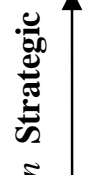 } & Germany & 4.8 \\
\hline & Czech Republic & 4.4 \\
\hline & Latvia & 0.6 \\
\hline \multirow{4}{*}{ 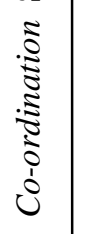 } & Poland & -1.8 \\
\hline & Slovakia & -2.8 \\
\hline & Hungary & -3.3 \\
\hline & Lithuania & -3.8 \\
\hline \multirow{2}{*}{ 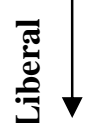 } & Estonia & -5.7 \\
\hline & USA & -8.3 \\
\hline
\end{tabular}

Source: Knell and Srholec, 2007

Table 2 - Baláž's composite index of co-ordination

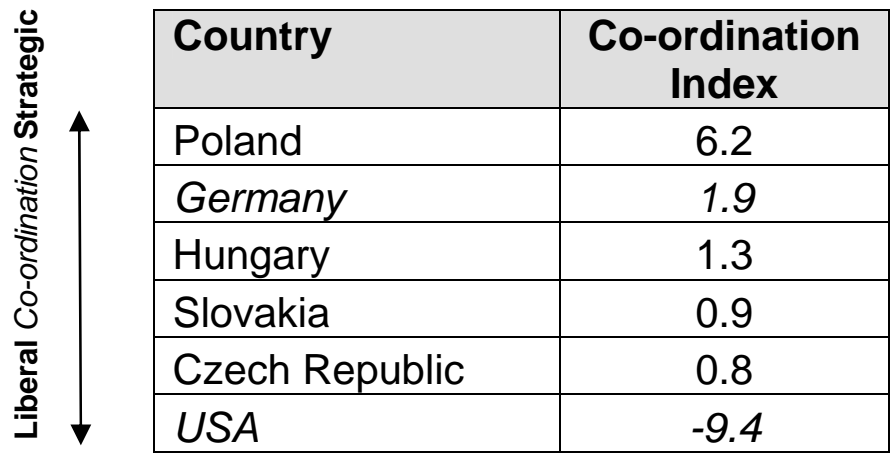

Source: Baláž, 2006 
Based on the reviewed literature, it is clear that there is a considerable consensus on the position of Estonia and Slovenia within the VoC framework. The smallest of the Baltic states approaches the ideal type of liberal market economy, while Slovenia is close to the co-ordinated market economy model. However, the picture is a little blurred when it comes to the other countries, especially within the Višegrad group. It is clear that different results and categorisations stem from the different methods being applied and the different variables being taken into consideration.

The varieties of capitalism approach is not a strictly-defined theory with its own procedures: it is a framework that is continually enriched by many scholars. This facilitates its application in further research into the comparative political economy. The next section constitutes an attempt to contribute to the contemporary knowledge of varieties of capitalism in central and eastern Europe.

\section{Composing the co-ordination index}

Post-communist economies in central and eastern Europe have undergone major changes in the past two decades. Transition to the market economy and the building of national institutions supportive of the market have not had the same pace and design in all countries. In order to grasp possible differences among the sample states, I have developed a numerical index that will express the strength and type of co-ordination within national economies. At this stage of the research, I am narrowing my index down to one-dimensional variables, although I am aware of possible shortcomings.

Taking into consideration all the aspects of the VoC concept, measuring the coordination of firms and other actors directly is almost impossible. However, Hall (2009: 454) offers a solution, commenting that:

The nature of co-ordination depends on the type of institutions available to support it.

Therefore, it is possible to grasp co-ordination by investigating the outcomes, or outputs, resulting from certain types of institutional arrangement. In the following analysis, I focus on the observable and measurable evidence of the institutional support evident in the real world. Institutions in the liberal market economy provide incentives for different behaviours than their counterparts in co-ordinated market economies, so this facilitates the observation and measurement of the outcomes typical of either type of co-ordination. Focusing on the observable behaviour of actors within the national economy should tell us more about both the institutional support and the character of co-ordination itself.

The selection of my sample stems from the logic of the institutional development of the market economies of post-communist countries. Regarding the varieties of capitalism approach, I narrowed the sample down to the group of eight post-communist states which entered the European Union in 2004. There are several arguments for this sampling, stemming from the character and particularities of the VoC approach. Limiting my sample to the Baltic states, V4 countries and Slovenia is especially important when it comes to the quantitative analysis. 
Before proceeding to the method of calculation, it is necessary to explain why a basic comparison of the new EU member states and 'western' countries is not appropriate. It is quite simple: centuries of development among 'western' economies have caused the values of many indicators to be positioned at a different interval than in the case of central Europe. A simple example will illustrate the issue: consider the indicator of stock market capitalisation, which is one of the most important features of the VoC approach. According to the theory, a higher stock market capitalisation identifies the presence of the liberal market economy model, since financial markets are the main source of finance for new investment. In contrast, a low level of stock market capitalisation is associated with the co-ordinated market economy model, since firms are not dependent on current profits and have access to long-term finance.

Below is a table showing the level of stock market capitalisation in Germany and the USA (two countries close to the ideal type, according to Hall and Soskice), as well as Slovenia and Estonia (two countries that represent liberal and co-ordinated market economies in central and eastern Europe).

Table 3 - Stock market capitalisation (2005 / latest available)

\begin{tabular}{|l|c|}
\hline Country & $\begin{array}{c}\text { Stock market capitalisation } \\
\text { (as \% of GDP) }\end{array}$ \\
\hline USA & 141.14 \\
\hline Germany & 46.17 \\
\hline Estonia & 27.01 \\
\hline Slovenia & 23.29 \\
\hline
\end{tabular}

Source: European Commission (Eurostat)

In compliance with the literature, stock market capitalisation is higher in the USA than in Germany, as well as in Estonia than in Slovenia. However, there is a clear difference between western states and post-communist ones. This can be explained by the length of time that different financial markets have been developing. Therefore, a simple comparison of the numbers between western and post-communist states is not always practical.

\section{Calculating the index}

Before I proceed to the method of calculation, it is necessary to explain and justify the selection of the variables. Several scholars have used different variables in their analyses and, thus, many of the indicators have become 'standard' in the VoC approach. Examples are union density; workplace representation; social protection expenditure; complex experts; collective bargaining coverage; centralisation; etc. (Feldmann, 2006; Bohle and Greskovits, 2007; Crowley and Stanojevic, 2009; etc.).

The $\mathrm{VoC}$ concept does not specify the exact indicators which best describe the processes of co-ordination, so I have selected variables representing all of the five key spheres of co-ordination identified by Hall and Soskice (2001). Observations were 
drawn from the 2003-2006 period, the latest for which comparable data were available. In order to secure the correct data and ensure accurate comparability, I used only reputable international databases as the data source. This is also to ensure that the same methodology was used to obtain the variable in each country. So far, I have identified eighteen suitable variables, of which eight refer to the two core areas of the VoC concept while the other ten refer to the remaining areas. A complete list of the variables chosen, as well as the data source, definition and observation period, is included in Appendix 1.

After collecting the data, they were coded on a scale from -1 to +1 , according to the following logic. The closer a number moves toward +1 , the stronger is the indication of a non-market/strategic co-ordination and, therefore, is suggestive of the existence of a co-ordinated market economy model. This holds true vice versa: a move toward -1 indicates a form of capitalism embedded by market tools, thus implying the existence of a liberal market economy model. The values of each indicator were scaled separately such that the value closest to the co-ordinated market economy model was automatically assigned +1 , while the value closest to the liberal market economy model was assigned -1 . The rest of the values were rescaled in order to preserve distance between the observed variables.

This way of coding has its limits, but I believe that these are outweighed by the advantages. The major shortcoming of this technique is that the analysis of a given dataset has a strong relational and comparative character and relates only to the countries included; the analysis says nothing about relationship to other countries or to regions outwith the dataset. However, this scaling system allows the addition of any country to the analysis in the future, or the application of the same method to a completely different set of countries or regions. At the same time, it also facilitates working with time-series data. On top of that, the values of every indicator being coded separately on the same scale enables us to compare different units of measurement (e.g. percentages, dollars, grades or rankings).

To make the comparison more interesting, I also constructed measurements and indices for the regions of 'the Baltics' and the 'Višegrad group' as if each were a single unit of observation. My approach considers individual national economies as single units of analysis, so the variables collected and used for the regional averages are unweighted.

Before taking the next step, it is important to realise that the key concept of this framework has two dimensions: the character and the strength of co-ordination. In order to carry out the statistical tests, the concept needs to be defined in a way that enables us to work with numbers. It was noted above that the variables were already coded in compliance with the VoC concept of the liberal or co-ordinated models - the values grouping closer to -1 (liberal) or +1 (co-ordinated).

Consequently, to determine the type of co-ordination mechanism, I apply an appropriate measurement of central tendency. In this case, I have used the arithmetic average of the median and the mean. The reason for doing so is simple: with a small dataset of eighteen variables, the use of the mean on its own carries a risk that the result will be considerably influenced by extreme values. On the other hand, using only the median might also belie the results: countries with more than half the observed variables 
being highest or lowest would be automatically assigned as an ideal type. Therefore, I consider the arithmetic average of the mean and the median to be the most appropriate measure of the central tendency for this set of data.

In order to test the strength of the institutional embedding of capitalism, I needed to employ a measurement of the variability of the data. For the purpose of this analysis, I chose the standard deviation, as it is a common measurement of the dispersion of values and helps to express the homogeneity of the data sample. According to the VoC concept, the more homogeneous the sample, the stronger the co-ordination, no matter the character.

The final index of co-ordination for the sample countries was calculated in the following way. The number expressing the character of co-ordination (the measurement of central tendency) was divided by a number representing the strength of co-ordination (the measurement of variance). In this way, stronger levels of co-ordination further fortify the co-ordination character. Ultimately, this means that the stronger the coordination, the higher the index we obtain given the character of the co-ordination.

Figure 2 - Co-ordination character of economic actors in central and eastern Europe

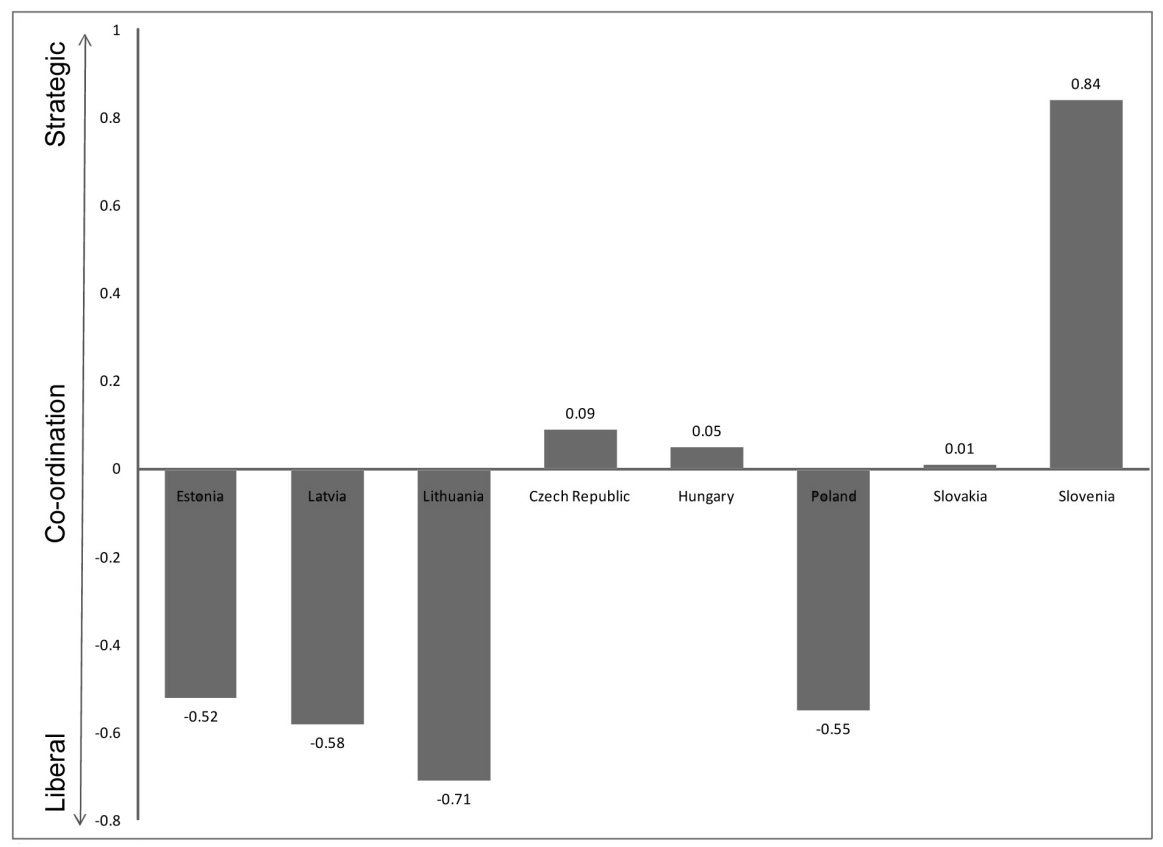

Source: author 


\section{Conclusions}

The current literature suggests that type of capitalism should vary between nations. To assess this suggestion, I constructed a co-ordination index that would allow easy cross-national comparison. The construction of a composite index has regard to the theory's key concept: co-ordination.

Figure 2 presents the index values for the eight post-communist countries. Institutional change does not occur very fast, as a rule. However, it is important to note that the observations used in this research were drawn before the global financial crisis hit central and eastern Europe and the co-ordination index corresponds to that period.

Figure 3 presents the co-ordination index. Countries are clustered geographically and visually distinguished by colour. The average values for the geographic regions are included.

Figure 3 - Co-ordination index

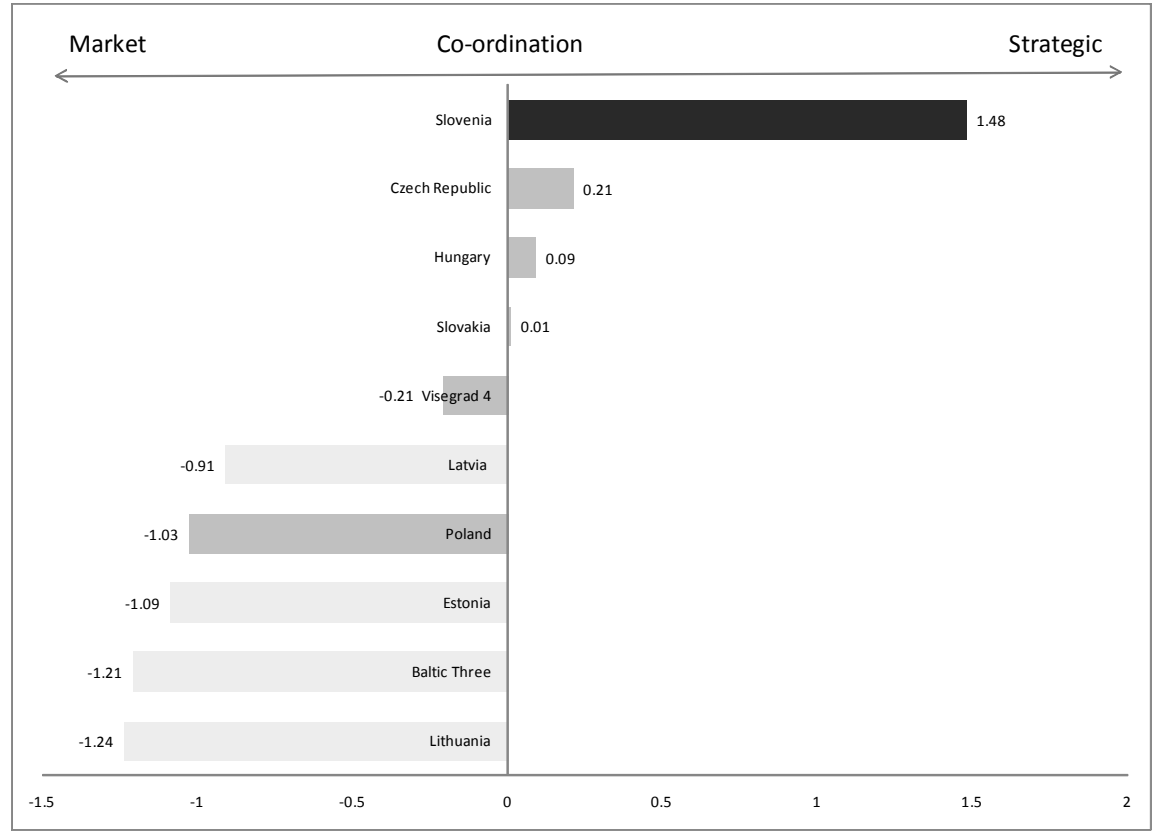

Source: author

The actual results of the research should not be too much of a surprise. It is shown in Figure 2 and Figure 3 that the measurement of the co-ordination of economic actors falls within the expected boundaries suggested by the current literature. The hypothesis of Feldmann, and Bohle and Greskovits and others who suggested that Slovenia is actually the closest to a co-ordinated market economy, while the Baltic countries are closest to a liberal one, are confirmed. However, there are a few noteworthy signals. 
What is most striking is the position of Poland within the sample. According to the variables observed, Poland could be categorised as a liberal market economy. Interestingly enough, according to the results, co-ordination in Poland leans more to the liberal market economy type than the case of Latvia.

Another point that should be highlighted is the positions of Estonia and Lithuania. Surprisingly, Lithuania scored the lowest, which means that the type of co-ordination in this country is more liberal than it is in Estonia. This is in contrast to up-to-date literature which suggests the opposite.

The position of Slovenia is strongly in line with previous research on this topic. Based on the index, we might conclude that the co-ordination of economic actors in Slovenia is closer to the co-ordinated market economy type than is the level of coordination in Lithuania to the liberal model.

Hungary, Slovakia and the Czech Republic seem to have their capitalisms not yet institutionally embedded. There is no evidence that liberal or co-ordinated institutions dominate their market economies.

However, it has already been noted that this analysis is strongly relational in the sense that any conclusions hold true only for comparisons reached within the sample. Despite this, the method of calculating the co-ordination index used here facilitates further research in time and in the application of the method to other regions. Once the co-ordination index is constructed, this will facilitate a comparison of the type of capitalism and the efficiency of public policies, or the economic performance of the states in question.

\section{References}

Amable, B (2003) The Diversity of Modern Capitalism Oxford University Press: New York.

Bohle, D and B. Greskovits (2007) 'Neoliberalism, Embedded Neoliberalism and Neocorporatism: Towards Transnational Capitalism in Central-Eastern Europe' West European Politics 30(3): 443-466, May.

Bluhm, K (2010) 'Theories of Capitalism Put to Test: Introduction to a debate on Central and Eastern Europe' Historical Social Research, No. 132, 35 (2):197-218.

Buchen, C (2005) 'East European Antipodes: Varieties of Capitalism in Estonia and Slovenia' prepared for the Pre-Publication Conference Varieties of Capitalism in Post-Communist Countries held at Paisley University, 23-24 September 2005, available online at:

http://www.uws.ac.uk/schoolsdepts/business/cces/documents/clemensbuchen.pdf [last accessed 3 December 2010].

Cernat, L (2001) 'Institutions and Economic Growth: What Model of Capitalism for Central and Eastern Europe?' paper prepared for the Conference Institutions in Transition, Slovenia.

Crowley, S and M. Stanojevic (2009) Varieties of capitalism, Power Resources and Historical Legacies: Explaining the Slovenian Exception paper prepared for pre- 
sentation at the 2009 Annual Meeting of the American Political Science Association, Toronto, Canada.

De Boer-Ashworth, E (2000) Global Political Economy and Post-1989 Change MacMillan.

Deeg, R and G. Jackson (2007) 'Towards a more dynamic theory of capitalist variety' Socio-economic Review 5(1): 149-179, January 2007.

Hall, P. A and D. W. Soskice (2001) Varieties of Capitalism: The Institutional Foundation of Comparative Advantage Oxford University Press: New York.

Hall, P. A and D. W. Gingerich (2009) 'Varieties of Capitalism and Institutional Complementarities in the Political Economy: An Empirical Analysis' British Journal of Political Science 39: 449-482.

Hall, P. A and R. C. R. Taylor (1996) 'Political Science and the Three New Institutionalisms' Political Studies XLIV: 936-957.

Hinton, P. R (2004) Statistics Explained Routledge: New York.

Feldmann, M (2006) 'Emerging Varieties of Capitalism in Transition Countries: Industrial Relations and Wage Bargaining in Estonia and Slovenia' Comparative Political Studies 39(7): 829-854, September.

Ingham, G (2008) Capitalism. Key Concepts Polity Press.

Klimplova, L (2009) Czech Republic and the Varieties of Capitalism Approach Lambert Academic Publishing.

Lane, D and M. Myant (2007) Varieties of Capitalism in Post-Communist Countries Palgrave-MacMillan.

Lane, D (2005) 'Emerging Varieties of Capitalism in Former State Socialist Societies' Competition \& Change 9(3): 227-247.

North, Douglass C (1990) Institutions, Institutional Change and Economic Performance Cambridge: Cambridge University Press.

Nölke, A and A. Vliegenthart (2009) 'Enlarging the Varieties of Capitalism: The Emergence of Dependent Market Economies in East Central Europe' World Politics 61(4): 670-702, October.

Ostrom, E (2005) Understanding Institutional Diversity Princeton: Princeton University Press.

Peters, B. G (1999) Institutional Theory in Political Science. The "New Institutionalism" London: Continuum.

Scharpf, F. W (1997) Games Real Actors Play. Actor-Centered Institutionalism in Policy Research Boulder: Westview Press.

Török, Á (2006): In-depth comment on the varieties of capitalism in the new member states, as well as on the key issues regarding competition and innovation Working Paper for the Lisbon Agenda Group. 
Vanhuysse, P (2007) 'Workers without Power: Agency, Legacies and Labour Decline in East European Varieties of Capitalism' Sociologicky časopis (Czech Sociological Review) 43(3): 495-522. 
Appendix 1 - List of variables used in statistical analysis

\begin{tabular}{|c|c|c|c|}
\hline Indicator & Operationalisation & Source & Year \\
\hline Trade union density & $\begin{array}{l}\text { Union members as percentage of all } \\
\text { employees in dependent employment }\end{array}$ & $\begin{array}{l}\text { EIRO / } \\
\text { Eurofound }\end{array}$ & 2006 \\
\hline $\begin{array}{l}\text { Employer organisation } \\
\text { density }\end{array}$ & $\begin{array}{l}\text { Percentage of employees employed by } \\
\text { companies who are members of an } \\
\text { employer organisation }\end{array}$ & $\begin{array}{l}\text { EIRO / } \\
\text { Eurofound }\end{array}$ & 2006 \\
\hline $\begin{array}{l}\text { Collective bargaining } \\
\text { coverage }\end{array}$ & $\begin{array}{l}\text { Percentage of employees covered by } \\
\text { collective agreements }\end{array}$ & $\begin{array}{l}\text { EIRO / } \\
\text { Eurofound }\end{array}$ & 2006 \\
\hline \multicolumn{2}{|l|}{ Workplace representation } & $\begin{array}{l}\text { EIRO / } \\
\text { Eurofound }\end{array}$ & 2006 \\
\hline \multicolumn{2}{|c|}{ Degree of bargaining centralisation } & $\begin{array}{l}\text { EIRO / } \\
\text { Eurofound }\end{array}$ & 2006 \\
\hline $\begin{array}{l}\text { Stock market } \\
\text { capitalisation }\end{array}$ & $\%$ of GDP & WB & 2005 \\
\hline $\begin{array}{l}\text { Domestic credit } \\
\text { provided by banking } \\
\text { sector }\end{array}$ & $\%$ of GDP & WB & 2005 \\
\hline Hi-tech exports & $\%$ of total EXP & Eurostat & 2005 \\
\hline Hi-tech employment & share of total EMP & Eurostat & 2005 \\
\hline Triadic patents & 00-03 av. per 10 million labour force & Eurostat & $\begin{array}{l}2000-03 \\
\text { av. }\end{array}$ \\
\hline $\begin{array}{l}\text { Gov. expenditures on } \\
\text { R\&D }\end{array}$ & 00-06 av. share of total & Eurostat & $\begin{array}{l}2000-06 \\
\text { av. }\end{array}$ \\
\hline $\begin{array}{l}\text { Social protection } \\
\text { expenditure }\end{array}$ & $\%$ of GDP, euro PPS & Eurostat & $\begin{array}{l}2000-04 \\
\text { av. }\end{array}$ \\
\hline $\begin{array}{l}\text { Shareholder rights } \\
\text { protection index }\end{array}$ & $\begin{array}{l}\text { Reflects shareholders' ability to mitigate } \\
\text { managerial opportunistic behaviour }\end{array}$ & ECGI & 2005 \\
\hline $\begin{array}{l}\text { Minority shareholder } \\
\text { protection index }\end{array}$ & $\begin{array}{l}\text { Regulatory provisions aimed at increasing } \\
\text { the relative power of minority } \\
\text { shareholders in the context of a strong } \\
\text { majority shareholder }\end{array}$ & ECGI & 2005 \\
\hline $\begin{array}{l}\text { Creditor rights } \\
\text { protection index }\end{array}$ & $\begin{array}{l}\text { Regulatory provisions that allow creditors } \\
\text { to force repayment more easily, take } \\
\text { possession of collateral, or gain control } \\
\text { over firm in financial distress }\end{array}$ & ECGI & 2005 \\
\hline Social expenditures & $\%$ of GDP & Eurostat & 2006 \\
\hline Youth unemployment & less than $25 \mathrm{yrs} ; \%$ of age group & Eurostat & 2004 \\
\hline \multicolumn{2}{|c|}{ Per capita social protection expenditure } & Eurostat & $\begin{array}{l}2000-03 \\
\text { av. }\end{array}$ \\
\hline
\end{tabular}

